\title{
KONTRIBUSI ILMU KALAM/FILSAFAT ISLAM DALAM PEMBANGUNAN KARAKTER BANGSA
}

\author{
M. Amin Abdullah \\ UIN Sunan Kalijaga \\ Anggota Komisi Kebudayaan, Akademi Ilmu Pengetahuan Indonesia
}

\begin{abstract}
The trend of Islamic sciences in the future, especially kalam Science/Islamic philosophy is a religion sciences that have to interact and dialogue with modern science, the social sciences and humanities. If scientific Kalam and Islamic Philosophy felt enough with himself (al-muhafadzah 'ala al-qadim al-shâlib), refusing to touch and connect with other scientific (wa al-akhdz bi al-jadid al-ashlah), then there is no future can be expected, morever their contribution to the development of the nation's character. This paper describes the themes of what is required to form the new religious (Islamic) worldview that can contribute to the development of the nation's character. Islamic sciences requires fresh ijtihad to deal with the contemporary of life, it is not enough just to repeating the experience of the past without looking how the development of the present and the future. Past (al-turâts) is still needed, but also needed a paradigm shift towards the present (al-hadâtsah) in view of the contemporary religious and solve problems, especially those related to the issue of character development in the format state of the nation (nation-states).
\end{abstract}

Kata kunci: karakter bangsa, ilmu-ilmu agama, sains modern

\section{Pendahuluan}

Sudah lama saya mengajar mata kuliah Pemikiran Kalam Modern di program Magister pascasarjana UIN Sunan Kalijaga. Mungkin sekitar 10 tahunan. Ketika pertama kali berjumpa dengan mahasiswa alumni S 1 dari berbagai perguruan tinggi di bawah Kementerian Agama, c.q Pendidikan Tinggi Agama Islam (Diktis), umumnya para mahasiswa bertanya-tanya, bahkan mempertanyakan apa itu Kalam Modern? Apa itu filsafat Islam modern? Apa ada itu Kalam/Filsafat Islam Modern? Apa itu Dakwah yang bercorak transformatif-progressif? Umumnya mereka penasaran, karena ketika di S 1 hampir-hampir tidak dikenalkan apa itu Kalam atau Dakwah Modern. Mungkin sudah dikenalkan, tetapi masih pada tahapan pengenalan awal. Belum mendalam. Belum dapat membentuk world view baru. Mahasiswa tidak hanya dari program S 1 dalam negeri, tetapi ada juga dari luar negeri, Lc dari al-Azhar, Kairo, Mesir. Umumnya, dari fakultas Ushuluddin al-Azhar, Kairo, Mesir. Sesekali ada satu-dua dari perguruan tinggi dari dalam negeri bukan dari Kementrian agama. Saya sebagai dosen pengampu, semula juga mencari-cari tema, topik, materi, pokok bahasan yang tepat serta buku dan atau literatur pendukung yang cocok untuk mengisi diskusi dengan mahasiswa peserta program tentang corak dan struktur bangunan berpikir Pemikiran Kalam Modern. Biasanya perkuliahan berjalan sampai 14 atau 16 kali pertemuan, dengan menggunakan sistem presentasi paper kelas oleh mahasiswa peserta program.

Setelah usai kuliah, saya tidak melakukan ujian akhir di kelas, yang biasa dikenal dengan UAS (Ujian Akhir Semester), tetapi bentuk tugas akhirnya adalah take home exam. Jarang juga saya minta agar makalah di perbaiki, karena makalah aturannya sudah diperbaiki sendiri oleh mahasiswa begitu ada masukan dari setiap diskusi kelas dalam perkuliahan sampai akhir. Yang biasa saya lakukan, saya 
hanya minta kepada mahasiswa untuk mencatat dan melaporkan kembali poin-poin penting apa saja yang mereka peroleh selama 14-16 kali pertemuan. Pengetahuan apa yang baru, pengetahuan yang transformatif-progressif, pengetahuan baru apa yang berbeda dari yang mereka ketahui selama mereka duduk di S 1, atau di pesantren bahkan di al-Azhar, Pakistan, Malaisia dan seterusnya atau ketika mereka berkecimpung dalam masyarakat atau perguruan tinggi. Macam-macam yang mereka tulis, karena tidak mudah memang menyimpulkan poin-poin pengetahuan baru apa yang pokok, yang dapat diserap dan mengesan bagi mahasiswa. Lebih-lebih jika mahasiswa ditanya ada shifting paradigm seperti apa dalam world view keagamaan mereka, yang mereka rasakan setelah mereka selesai mengikuti perkuliahan.

Setelah membaca feedback, catatan dan laporan mahasiswa tentang apa yang mereka peroleh selama mengikuti perkuliahan Pemikiran Kalam Modern serta mengkaji dan merunut ulang topik-topik bahasan melalui tugas pembacaan beberapa artikel, buku dan literatur yang diperkenalkan di awal kuliah, maka mata kuliah ini semacam atau menyerupai Fikih Sosial, Kalam Sosial dan Falsafah Islam Sosial yang diperluas.Untuk memberi gambaran apa yang dimaksud dengan Kalam Sosial, Falsafat Islam Sosial atau Dakwah Sosial yang diperluas, berikut ini adalah item-item, subheading dari catatan dan laporan yang ditulis mahasiswa yang telah mengikuti perkuliahan Pemikiran Kalam Modern. ${ }^{1}$ Saya akan mengambil contoh dari sebagian catatan mahasiswa dan mengutarakannya kembali disini, dengan harapan dapat mengisi kekosongan model model pembelajaran, pengajaran dan perkuliahan Kalam/Filsafat Islam atau Fikih Sosial dan Dakwah Sosial yang baru, yang sedang dicari-cari sosok bentuknya di perguruan tinggi agama Islam di tanah air, baik negeri maupun swasta, yang kiranya dapat berkontribusi dalam pembangunan karakter bangsa (Character dan Nation building).

\section{Tema-Tema dalam Kajian Kalam/ Filsafat Islam Kontemporer}

Setidaknya ada sembilan tema atau topik besar yang perlu dibahas oleh perkuliahan dan pengajaran Kalam Sosial/Filsafat Islam Sosial, Fikih Sosial dan Dakwah Sosial era kontemporer, yaitu 1) Nash dan penafsiran atas nash, 2. Harkat dan martabat kemanusiaan (al-Karamah al-Insaniyyah), 3) Islam dan Sains modern, 4) Ijtihad keilmuan kontemporer, 5) Fikih wanita (Fiqh al-nisa' al-mu'asir), 6) Dialog antar budaya dan agama (al-Hiwar), 7) Fikih Sosial-politik, 8) Fikih dan Dakwah Universal dan 9) Fikih dan Dakwah Kewargaan.

Tidak hanya sembilan, sesungguhnya. Masih dapat ditambah dengan item-item lain yang relevan, namun catatan yang terpokok dan perlu digarisbawahi disini adalah titik tekan diskusi dan pembahasan Kalam,Falsafah, Fikih dan Dakwah Sosial era kontemporer adalah penekanannya pada pembentukan world view dan nilai saling keterkaitan dan keterhubungan antara satu item pembahasan dengan item pembahasan yang lain.

Penekanan ini penting karena dalam kesalingketerkaitan itulah yang akan membentuk jaringan pola berpikir yang membentuk keutuhan world view, yaitu pandangan dunia keagamaan (Islam) yang komprehensif dan segar. Pandangan dunia keagamaan Islam yang fresh, baru dan transformatif, yang relevan dengan tantangan perubahan sosial dan perkembangan ilmu pengetahuan. Jika masing-masing tema berdiri sendiri-sendiri, tak terkait antara satu dan lainnya, maka hal tersebut tidak akan membentuk tatanan world view keagamaan Islam yang utuh dan komprehensif, yang dapat membentuk pembangunan

${ }^{1}$ Tulisan ini adalah pengembangan lebih lanjut dari laporan catatan mahasiswa sebagai tugas akhir mata kuliah Pemikiran Kalam Modern. Terima kasih kepada Masykur Arif, Ade Humaidi Pane dan Arif Rahman Hakim serta Jemil Firdaus yang telah merekap tema-tema kuliah menjadi subheading seperti yang diminta. 
karakter kehidupan sosial berbangsa dan bernegara. Corak atomistik seperti itu lah yang biasa mewarnai corak berpikir Kalam/Aqidah, Falsafah Islam, Fikih dan Dakwah era Klasik, pra-modern, pre-nation states.

Tulisan ini akan menjelaskan beberapa komponen, item-item atau tema-tema apa saja yang seharusnya dibahas dalam Kalam/Aqidah, Falsafah Islam, Fikih dan Dakwah Sosial era kontemporer yang sekiranya dapat berkontribusi dalam pembanguna Karakter bangsa. Sisi epistemologis dari saling keterkaitan pembahasan antara satu item pokok bahasan dengan item pokok bahasan yang lain adalah kata kunci yang hendak digarisbawahi disini. Kalam/Aqidah, Falsafah Islam, Fikih, Kalam dan Dakwah Sosial modern memerlukan seperangkat keilmuan lain, selain yang diambil dari Fiqh, Usul al-figh dan Qawaid al-fiqhiyyah yang umumnya telah tersedia dalam buku literatur keislamanyang baku (kitab kuning).Dengan cara mengawinkan dan mencangkokkan beberapa disiplin ilmu yang lain, khususnya sains modern ${ }^{2}$, ilmu sosial dan humanities kontemporer dalam bangunan cara berpikir Kalam/Aqidah, Falsafah Islam, Fikih, Kalam dan Dakwah, maka kebutuhan mendesak untuk melakukan apa yang disebut Abdullah Saeed sebagai fresh ijtihad dalam segala lini kehidupan akan secara bertahap dapat terpenuhi.

\section{Hubungan antara nash (text) dan penafsiran terhadap nash (text).}

Ciri fundamendal budaya Islam adalah ketergantungannya yang sangat kuat terhadap nash atau text.Dalam beberapa tulisan terdahulu, saya menyebutnya dengan istilah hadarah al-nash (budaya teks). ${ }^{3}$ Hampir seluruh kegiatan dan amalan sehari-hari, lebih-lebih yang terkait dengan ibadah, baik yang menyangkut keyakinan (aqidab) atau rukun imanmaupun ritual ('ibadab) atau rukun Islam yang dilakukan sehari-hari, semuanya hampir berlandaskan pada nash atau teks. Tanpa landasan nash (ayat; dalil), maka keimanan dan ibadahnya akan tertolak (mardud), begitu yang biasa kita pelajari dan ketahui dari bangku sekolah atau forum-forum majelis taklim. Sampai disini barangkali memang tidak ada masalah, karena masing-masing agama memang mempunyai aturan dan regulasi tersendiri yang berbeda dari aturan dan regulasi yang dimiliki oleh pengikut agama-agama yang lain.

Namun agama tidak hanya terkait dengan keyakinan (aqidab) dan ritual ('ibadab) semata. Agama juga terkait dengan persoalan-persoalan lain, seperti kepemimpinan(leadership) yang bersentuhan dengan sistem kenegaraan dan kepemerintahan, sistem moral (morality) termasuk tata pergaulan antara sesama manusia di luar kelompok agamanya, kelembagaan (institution) sosial, pendidikan, ekonomi, belum lagi yang terkait dengan alat-alat, simbol-simbol yang dipergunakan dan seni (art dan tools). Dalam wilayah kelompok yang terakhir ini (leadership, morality, institution dan art) agak sulit jika semuanya harus berlandaskan dengan nash atau teks. Dalam bahasa agama Islam biasa dikenal adagium "alNusus mutanabiyah wa al-waqa'i' ghairu mutanahiyah” (Nash atau teks itu terbatas sedangkan peristiwaperistiwa sejarah kemanusiaan tidaklah terbatas). Kelompok yang terakhir ini terkena hukum perubahan

\footnotetext{
${ }^{2}$ Buku baru yang terbit tahun 2014 adalah karya Nidhal Guessoum, Islam's Quantum Question: Reconciling Muslim Tradition and Modern Science. Diterjemahkan ke dalam bahasa Indonesia oleh Maufur, Islam dan Sains Modern, (Bandung: PT Mizan Pustaka, 2014).

${ }^{3} \mathrm{M}$. Amin Abdullah, Islamic Studies di Perguruan Tinggi: Pendekatan Integratif-interkonektif, (Yogyakarta: Pustaka Pelajar, 2006), khususnya halaman 184-226. Ibrahim M. Abu-Rabi’ menyebutnya bahwa Sejarah dan Pemikiran Muslim dari dahulu hingga sekarang dan sampai kapanpun adalah merupakan produk dari salingbertukarnya posisi yang sangat kompleks antara unsur manusia, "the buman"dan unsur ketuhanan, "the divine”. Dengan kata lain, antara teks-teks agama dan faktor-faktor sosioekonomi dan politik yang mengitarinya. Lebih lanjut Ibrahim M. Abu-Rabi', "A Post-September 11 Critical Assessment of Modern Islamic History”, dalam Ian M. Markham dan Ibrahim M. Abu-Rabi' (Eds.), 11 September: Religious Perspectives on the Causes and Consequences, (Oxford: Oneworld Publications, 2002), h. 30.
} 
sejarah, karena budaya dan peradaban umat manusia (buman experience) terus berkembang sesuai dengan sejarah dan perkembangan ilmu pengetahuan, nilai-nilai dan rasionalitas, pertemuan dan kontak budaya dengan bangsa-bangsa lain, perkembangan sains dan teknologi dan begitu seterusnya. ${ }^{4}$

Dalam konteks seperti itu, maka para ulama, scholars, intelektual, aktivis dan ilmuan Muslim kontemporer, khusus para perumus Fikih, pemikir Kalam dan Falsafah serta pegiat Dakwah Sosial era kontemporer perlu selalu berpikir keras bagaimana menghubungkan dan mendialogkan antara apa yang diyakini-diimani atau dianggap sebagai hal-hal yang tetap (al-Tsawabit) - sebutlah misalnya kedua wilayah yang disebut pada bagian pertama diatas - dan wilayah yang berubah-rubah (almutaghayyirat), yang terhimpun dalam bagian kedua disebut diatas. Apa yang dapat disepakati oleh orang-orang Muslim dimanapun mereka berada dan apa saja yang tidak dapat dan tidak harus disepakati oleh berbagai Muslim di dunia? Dari sini kemudian berkembang istilah-istilah baru yang belum atau tidak begitu di kenal di era diskusi Kalam atau Aqidah klasik dan medieval seperti pembedaan antara wahyu dan pemahaman atau penafsiran terhadap wahyu (Abdul Karim Sorous), asbab al-nuzul macro dan micro (double movement) (Fazlur Rahman), al-makna (pencarian makna asli) dan al-maghza atau signifikansi(pencarianmakna saat ini) (Nasr Hamid Abu Zaid), antara asbab al-nuzul 'qadim' (pemahaman makna asbab al-nu₹ul era klasik) dan asbab al-nuгul 'jadid' (pemahaman makna asbab alnuzul era modern dan masa kini) (Abdullah Saeed) dan begitu seterusnya. ${ }^{5}$

Kalam, Falsafah, Fikih dan Dakwah Sosial modern pada dasarnya adalah persoalan bagaimana manusia Muslim yang hidup di era kontemporer sekarang ini memecahkan persoalan keterhubungan, keterpisahan, keterkaitan dan dialektika antara nash atau teks dan realitas. Meminjam istilah yang digunakan Hasan Hanafi, min al-nash ila al-waqi ${ }^{*}$. Tatanan sosial, politik, ekonomi, budaya, ilmu pengetahuan yang berubah, berbeda dan berkembang secara radikal dari tatanan sosial, politik, ekonomi, budaya, seni dan ilmu pengetahuan era klasik-skolastik adalah bagian dari problem ijtihad kontemporer. Diperlukan ijtihad kontemporer, bahkan ijtihad yang segar (fresh ijtihad), untuk membahas keberagamaan manusia Muslim era millinium baru sekarang. Keterkaitan, keterhubungan dan perbedaan dan keterpisahan antara nash dan penafsiran terhadap Nash dalam setiap periode jaman yang dilalui oleh sejarah kebudayaan Islam (klasik, tengah, modern, posmodern) adalah tema sentral dan bahan diskusi penting yang tidak dapat dipisahkan dari keilmuan Kalam, Falsafah, Fikih dan Dakwah modern, lebih-lebih apa yang disebut Kalam, Falsafah, Fikih dan Dakwah Sosial era kontemporer.

\section{Harkat dan martabat kemanusiaan (al-karamab al-insaniyyab)}

Masalah-masalah kemanusiaan yang fundamental, seperti kemiskinan, kesehatan, pendidikan, keterbelakangan ekonomi, korupsi, kolusi dan nepotisme, penyalahgunaan obat terlarang, penyalahgunaan jabatan dan kekuasaan (abuse of power), narkotika dan lain-lain menjadi tema sentral dalam pembahasan Kalam, Falsafah, Fikih dan Dakwah Sosial modern. Kalam klasik, seperti yang dirumuskan dalam pemikiran Asy'ari, Mu'tazilah, atau Maturidiyah, dan lain-lain yang hanya membahas persoalan kekekalan dan kefanaan al-Qur'an (Qadim atau Jadid), kafir dan mukmin, keadilan Tuhan

${ }^{4}$ Jasser Auda, Maqasid al-Shariah as a Philosophy of Islamic Law: A Systems Approach, (Herndon,USA: The International Institute of Islamic Thought, 2008), h. 142-191.

${ }^{5} \mathrm{M}$. Amin Abdullah, "Metode Kontemporer Dalam Tafsir al-Qur'an: Kesalingterkaitan Asbab al- Nuzul al-Qadim dan al-Jadid dalam Tafsir al-Qur'an Kontemporer”, Jurnal Studi Ilmu-ilmu Al-Qur'an dan Hadis, Vol. 13, No. 1, Januari 2012, h. 121.

${ }^{6}$ Hasan Hanafi, Min al-Nass ila al-Waqi': Muhawalah li i'adati binai ilm usul al-fiqh, Buku 1 dan 2, (al-Qahira: Markaz al-Kitab li al-nasyr, 2004 dan 2005). 
(baca: bukan keadilan manusia), dan masalah dosa besar dan kecil, tentu sudah tidak begitu relevan lagi untuk diperdebatkan pada saat ini. Tema-tema lama ini terlalu bercorak spekulatif, dan jika diterapkan secara serampangan, tidak hati-hati, tanpa dilapisi etika sosial yang kuat, maka Kalam dan Dakwah klasik dan medieval atau bercorak lama ini akan sangat mudah mengantarkan orang Muslim membentuk pola pikir sosial yang bercorak ta’ifiyyah-madzhabiyyah- hizbiyyah (sektarian-parochialistikprimordialistik), mudah melontarkan tuduhan murtad, kafir (takfir), munafiq, bid'ah terhadap orang, golongan atau kelompok lain yang tidak semadzhab, sepaham, segolongan, sekelompok, apalagi yang tidak seagama, seperti yang biasa kita dengar dan saksikan dalam intern masyarakat Muslim sendiri belakangan ini. Golongan Sunni dan Syi'iy, misalnya, di berbagai tempat di dunia Muslim tidak pernah akur, penuh kekerasan dan konflik. Jenis pemikiran keagamaan (Islam) lama seperti ini umumnya memang tidak dan kurang menghargai buman dignity (al-karamah al-insaniyyah).

Tidak hanya itu. Kalam, Falsafah, Fikihdan Dakwah corak lama ini tidak pernah menyentuh psikologi keluarga Muslim dan psikologi sosial umat beragama secara umum. Bagaimana menciptakan dan mengkondisikan keluarga yang hangat, ramah, sehat, saling menghargai, saling menyayangi, komunikatif, melindungi keutuhan keluarga, mengatasi problem broken home, mengelola kekecewaan, menghadapi problem perceraian, kekerasan dalam rumah tangga, permasalahan yang timbul akibat poligami (bagi yang mudah tergoda mempraktikkan poligami) dalam kehidupan keluarga dan begitu seterusnya. Apalagi family planning (tandzim al-nasl). Umumnya, hidup yang kompleks dianggap dapat diselesaikan hanya lewat satu pintu aqidah dan ibadah, tetapi tidak atau kurang dikaitkan dengan perkembangan dan pertumbuhan sejarah institusi keluarga dan disiplin ilmu pengetahuan yang lain dalam upaya menyelesaikan problem kehidupan seperti psikologi keluarga, psikologi wanita, psikologi sosial dan begitu seterusnya.

Kalam, Falsafah, Fikih dan Dakwah keagamaan yang bercorak lama tersebut hanya cocok pada zamannya dan tidak harus diikuti begitu saja saat sekarang ini tanpa diiringi pertanyaan dan perspektif yang kritis. Zaman telah berubah. Pendidikan telah merubah segalanya, yang tentu saja berakibat pada perubahan muatan pengalaman dan penghayatan terhadap pemikiran Kalam dan Filsafat Islam. Maka tidak bisa dipungkiri, apabila rumusan Kalam, Falsafah, Fikih dan Dakwah Sosial modern dan kontemporer juga dituntut untuk berubah dan berbeda dari rumusan Kalam, Falsafah, Fikih dan Dakwah klasik, medieval, pra-moderen. Kalam dan Falsafah Islam modern, seperti yang dirumuskan M. Arkoun, Fazlur Rahman, Abdullah Saeed, Omit Safi, Fethullah Gulen, Tariq Ramadan, dan lain-lain, tidak mau lagi terjebak pada permasalahan Kalam klasik yang cenderung spekulatif. Mereka, para pemikir Muslim kontemporer, berusaha menyentuh kebutuhan zaman yang dihadapi saat ini, yakni masalah-masalah kemanusiaan kontemporer. Mereka merasa memiliki tantangan dan tugas sejarah untuk merumuskan pemikiran Kalam, Falsafah atau pemikiran keagamaan Islam baru yang sesuai dengan konteks zaman kontemporer, termasuk era Keindonesiaan, era millinium baru, seperti saat sekarang ini, khususnya setelah ditemukan dan dikembangkannya sains, ilmu-ilmu sosial dan kemanusiaan yang baru paska abad ke $18 .^{8}$

${ }^{7}$ Pemikir Muslim kontemporer umumnya menekankan pentingnya buman dignity atau al-karamah al-insaniyyah. Lebih lanjut Abdullah Saeed, Interpreting the Qur'an: Toward Contemporary Approach, (London: Oneworld Publications, 2006), h. 3; Mashood A. Baderin, International Human Rights and Islamic Law, Oxford: Oxford University Press, 2003; Abdullahi Ahmed alNaim, Toward an Islamic Reformation: Civil Liberties, Human Rights, and International Law, (New York: Syracuse University Press), 1990 .

${ }^{8}$ Hasan Hanafi dan M. Abid al-Jabiri, Hiwar al-Masyriq wa al-Maghrib: Nabw i'adati bina'i al-fikr al-qaumi al-araby, (Beirut: almu'assah al-arabiyyah li al-dirasah wa al-nasyr, 1990), h. 58-9. 
Pendekatan world view Kalam klasik yang dipakai untuk menjelaskan masalah-masalah kemanusiaan kontemporer sudah tidak memadai. Hingga sekarang, banyak umat Islam yang masih terbelakang. Negara-negara yang dianggap sebagai negara yang berpenduduk mayoritas Islam, ratarata masuk dalam kategori dunia ke-3. Oleh karena itu, Kalam, Falsafah, Fikih dan Dakwah modern yang bertolak dari masalah-masalah kemanusiaan universal yang riil, seperti masalah kemiskinan, ekonomi kerakyatan, keadilan, tindakan non-diskriminatif, kesehatan, dan pendidikan sangat mendesak untuk dirumuskan dan dipecahkan. Salah satu pertanyaan penting yang patut diungkapkan oleh Kalam Sosial dan Fikih sosial modern adalah bagaimana cara memahami Tuhan - dalam arti ideologi keagamaan Islam yang mampu untuk menghapus kemiskinan, baik kemiskinan struktural maupun kemiskinan natural? Bagaimana corak pendidikan Akhlak individu dan sosial yang dapat menanggulangi godaan untuk tidak melakukan tindakan kekerasan atas nama agama, penyalahgunaan jabatan dan kekuasaan, kejahatan narkoba, penyakit sosial semisal prostitusi? Belum lagi korupsi, kolusi dan nepotisme. Disinilah perlunya dirumuskan pemikiran Kalam, Falsafah, Fikih dan Dakwah Sosial baru, yang fresh. Kalam atau world view keagamaan baru dan segar, yang dapat membebaskan manusia Muslim dari kemiskinan dan keterbelakangan dalam arti luas sangat dibutuhkan. Dan inilah salah satu unsur yang sangat dipentingkan dalam Kalam, Falsafah, Fikih dan Dakwah Sosial modern. Kalam dan Falsafah Ketuhanan dan lengket dan tidak jauh dari problem aktual kemanusiaan dan cara-cara untuk mengatasi dan menanggulangi berbagai persoalan sosial dengan menggunakan berbagai disiplin keilmuan (pursuasive) dan bukan dengan cara-cara kekerasan (coercive).

\section{Islam dan sains modern}

Kalam, Falsafah, Fikih dan Dakwah Sosial modern tidak menolak keterlibatan sains (fisika, kimia, biologi, dan lain-lain). ' Juga tidak menolak keterlibatan ilmu-ilmu sosial (sosiologi, antropologi, psikologi, sejarah dan lain-lain) dan humanitas kontemporer (isu-isu kemanusiaan universal seperti hukum dan HAM, keadilan Gender, hak-hak anak, family planning (tanzim al-nash), dialog antar agama dan budaya, kekerasan yang mengatasnamakan agama, perubahan iklim) dalam membentuk cara pandang baru keagamaan dan keilmuan (Aqidab), pola komunikasi dan tata pergaulan antar sesama (Mu'amalah) dan perilaku hidup sehari-hari dalam kehidupan pribadi, keluarga dan masyarakat (Akblak) keagamaaan Islam. ${ }^{10}$ Tidak seperti Kalam, Falsafah, Fikih dan Dakwah klasik tidak bersentuhan dengan sains, dan hanya mencukupkan diri pada teks (nash) dan tingkat ilmu pengetahuan manusia saat itu atau ijma' ulama saat itu. Barangkali karena pada masa klasik, pra-moderen, belum berkembang ilmu-ilmu sains, apalagi sosial sains, sehingga tidak heran apabila Kalam, Falsafah Islam, Fikih klasik, pra-moderen, tidak bersentuhan dengan sains. Ilmuan, cendekiawan dan ulama Fikih Sosial dan Kalam Sosial modern era sekarang, yang sudah mengetahui dan bersentuhan dengan perkembangan sains kealaman atau ilmu-ilmu sosial, mau tidak mau, jika tidak ingin disebut corak pemikiran keagamaannya disebut ketinggalan zaman (out of date; obselete) harus mau secara ikhlas

${ }^{9}$ Keputusan Mahkamah Konstitusi (MK) yang memperrtimbangkan masukan dari ilmu pengetahuan, dalam hal ini adalah DNA, dalam kasus gugatan Machica Mokhtar yang menuntut hak keperdataan anak hasil kawin sirri nya yang tidak tercatat, menginspirasi bagaimana temuan ilmu pengetahuan dapat digunakan untuk mengoreksi kesepakatan (ijma) sosialkeagamaan era klasik (anak yang hanya dapat dinisbahkan kepada ibu yang melahirkannya, ummul walad) ketika belum dapat ditemukan bukti ilmiah yang dapat dipertanggungjawabkan yang dapat menentukan ayah biologis adari anak tersebut.

${ }^{10}$ Ibrahim M. Abu-Rabi', A Post - September 11 critical assesment of modern Islamic history", dalam Ian Markham dan Ibrahim M. Abu Rabi' (Eds.), 11 Sepetember: Religious Perspectives on the Causes and Consequences, (Oxford: Oneworld Publications, 2002), h. 21-52 
berintegrasi dengan sains. Jika tidak, maka corak kualitas Aqidah, Mu'amalah dan Akblaq-nya akan terpengaruh. ${ }^{11}$

Jika tidak bisa berintegrasi, paling tidak harus bisa saling berdialog dan berkomunikasi. Saling memberi masukan, mendengar kritik dari berbagai disiplin ilmu adalah kebutuhan bagi kehidupan manusia era millinium baru sekarang. Multidisiplin, interdisiplin dan transdiplin adalah kebutuhan jaman saat ini, lebih-lebih dalam persoalan kehidupan beragama. Kebijakan linearitas tidak cocok diterapkan dalam bidang kajian agama dan keagamaan karena akan membentuk corak keberagamaan dan pemahaman keagamaaan yang sempit dan myopic. Saya mengenalkan cara berpikir era millinium baru ini dengan istilah integrasi-interkoneksi antar berbagai disiplin keilmuan ${ }^{12}$. Nidhal Guessoum menyatakan lebih tegas lagi bahwa pengetahuan agama, termasuk Islam, tidak bisa lagi mempertahankan hegemoni dan sikap statisnya. Jika sikap statis-dogmatis-hegemonik ini yang dipilih dan dipertahankan, maka ilmu-ilmu keagamaan akan bertentangan atau bahkan akan tergilas oleh perkembangan ilmu pengetahuan modern, dan akibatnya prinsip-prinsip dasar keagamaan Islam akan semakin terasa asing dan ketinggalan jaman (kadaluwarsa), untuk tidak menyebutnya expired. Berikut kutipannya:

"... The next important issue is the need to engage the Islamic scholars in a serious dialogue and convince them that scientists have much to say on topics that have for too long remained the monopoly of the religious scholars and their discourse. While there is no doubt in people's mind that human knowledge evolves and grows, it is often understood that religions, especially Islam, are (is) absolute, immutable and transcendent principle, which are set in rigid frames of reference. But we know today that religions - and Islam is no exception - cannot afford to adapt a stationary attitude, lest they find themselves clashing with and overrun by modern knowledge, and religious principles appear more quaint and obselete"13.

Sebenarnya, Kalam klasik tidak sepenuhnya memisahkan diri dari perkembangan pengetahuan di dunia pada saat itu. Seperti hasil penelitian Josef van Ess yang menemukan bahwa rumusan-rumusan dan cara pandang keagamaan Islam yang diwakili dalam perdebatan Kalam klasik memuat pola dan corak perdebatan yang menyerupai perdebatan intelektual di era Yunani, baik yang bercorak Stoic maupun Aristotle. Ternyata, pola pikir Aristotle dalam pemikiran Islam tetap saja tidak dapat menaklukkan dan tidak dapat keluar dari hegemoni cengkeraman dan pengaruh kuat pola pikir Stoic dalam Islam ${ }^{14}$. Ini membuktikan bahwa Kalam klasik tidaklah unik, karena ternyata sebahagian pola dasar berpikirnya (the way to think) adalah serupa belaka dengan pengalaman bangsa-bangsa lain di dunia sebelum Islam meskipun keunikannya tetap saja ada karena dalam pemikiran Islam ditambah kekuatan argumen yang diperoleh dari kutipan dari wahyu maupun hadits. Jika pola berpikir Kalam klasik saja mau membuka diri terhadap ilmu pengetahuan dan pola berpikir dari luar wilayah Arab, apakah Kalam modern mau menutup diri dari perkembangan sains mutakhir yang cukup pesat baik

${ }^{11}$ Kasus dimakzulkannya bupati Garut (2013) dari jabatannya sebagai bupati kepala daerah oleh Presiden Republik Indonesia beberapa waktu yang lalu adalah contoh yang paling sulit ditolak. Begitu juga beberapa tokoh partai politik (Islam) yang terjerat kasus korupsi dan korupsi di KPK. Kasus tersebut bukan kebetulan, tetapi adalah contoh yang paling jelas dari corak pemahaman keagamaan Islam lama (Figh dan Kalam atau world view keagamaan Islam lama) yang tidak atau belum bisa melakukan dialog dengan perkembangan pengalaman baru manusia (buman experience) yang antara lain didorong karena keberhasilan pendidikan dan perjumpaannya dengan falsafah, ilmu-ilmu sosial dan bumanities baru.

${ }^{12}$ Pidato inaugurasi saya sebagai anggota Akademi Ilmu Pengetahuan Indonesia (AIPI), "Agama, Ilmu dan Budaya: Paradigma Integrasi-interkoneksi keilmuan”, Yogyakarta, 3 September 2013. Dapat diakses di website AIPI http://goo.gl/ $43 \mathrm{~m}$ TBI

${ }^{13}$ Nidhal Guessoum, Islam's Quantum Question: Reconciling Muslim Tradition and Modern Science, (London dan New York: I.B. Tauris and Co Ltd., 2011), h. 343-4.

${ }^{14}$ Josef van Ess, "The logical Structure of Islamic Theology", dalam Issa J. Boullata (Ed.), An Anthology of Islamic Studies, (Montreal: McGill Indonesia IAIN Development Project, 1992). 
di Barat maupun di Timur? Tentu Kalam Sosial, Falsafah sosial, Fikih Sosial modern dan terlebihlebih Dakwah Sosial modern harus mau membuka diri, jika ilmu Kalam, Filsafat, ilmu Fikih dan ilmu Dakwah ingin terus berkembang menuju kesempurnaan dan kematangannya.

Fikih Sosial, Kalam Sosial dan Dakwah Sosial modern yang berintegrasi dan berinterkoneksi dengan sains, akan memunculkan pandangan-pandangan baru di bidang pemikiran keagamaan Islam dan pembentukan world view (pandangan keagamaan) Islam yang baru dan segar. Sebab, bagaimanapun juga metode dan pendekatan ilmu-ilmu empiris dalam sains memang benar-benar baru, sehingga sangat mungkin untuk menemukan rumusan-rumusan baru dan segar dalam Kalam, Falsafah, Fikih dan Dakwah apabila menggunakan pendekatan empiris sebagaimana yang berkembang dalam ilmu sains. Rumusan-rumusan Fikih, Kalam dan Dakwah modern akan terasa lebih nyata dan realistis, untuk tidak menyebutnya lebih nyaman atau lebih comfortable, dibandingkan dengan rumusan-rumusan Kalam klasik yang bersifat spekulatif, ideologis, bahkan seringkali bercorak, berkonotasi dan bermuatan politis.

\section{Ijtibad Keilmuan Kontemporer}

Langkah selanjutnya bagi ilmu-ilmu keislaman seperti Kalam, Falsafah, Fikih, Hukum, Pendidikan dan Dakwah adalah membuka selebar-lebarnya pintu ïtihad. Pemikiran keagamaan Islam telah membeku sejak, menurut Mohammad Arkoun, abad ke-12 sampai abad ke-19. Tertutupnya pintu ijtihad mengakibatkan- dalam bahasanya Fazlur Rahman - ilmu Kalam, ilmu-ilmu Fikih dan ilmu-ilmu dasar lain dalam Islam (Ulum al-din) mengalami proses ortodoksi (pembekuan). Metode dan pendekatan ilmu Kalam, ilmu Fikih dan ilmu Pendidikan dan Dakwah tidak mengalami perkembangan yang cukup berarti. Dampaknya terhadap corak pemahaman agama Islam menjadi sempit, myopic, terbatas dan terjebak pada kotak-kotak maď̨hab cara peribadatan, dan blok-blok sempit afiliasi sosial-politik. Madz̧ab pemikiran Kalam sunni dan madð̧ab pemikiran Kalam syi'iy, misalnya, ketika menggumpal dalam pengelompokan afiliasi sosial-politik menjadi begitu akutnya sehingga sangat emosional, sektarian dan penuh dengan kekerasan.

Model pemikiran Kalam, Fikih, Pendidikan dan Dakwah dan Ulumu al-din klasik pada umumnya terpeleset jatuh pada uraian tentang usulal-madz̧bab dan atau usul al-firaq, tapi kurang dan tidak lagi tertarik dan babkan melupakan tugas utamanya yang semula adalab untuk membahas secara mendalam dan radikal tentang dasar-dasar fundamental agama secara universal (usul al-Din). Menggunakan bahasa Persyarikatan Bangsabangsa, mereka lebih mementingkan distinctive values yang mereka miliki masing-masing tetapi kurang bahkan tidak menggali dan memikirkan shared values yang dimiliki oleh berbagai kelompok keislaman dan kemanusiaan yang ada. Kelompok-kelompok pemahaman keagamaan dan keislaman yang terlembagakan dalam sekte-sekte, al-firaq al-islamiyyah, atau organisasi-organisasi sosial-politik menjadi sangat kaku, membuat pagar pembatas yang tinggi, tanpa lagi dapat saling berhubungan sosial-politik secara fleksibel, ramah dan tidak saling bertegur sapa antar kelompok yang satu dengan kelompok yang lain karena kepentingan-kepentingan sosial-politik-ekonomi masing-masing.

Tidak mudah memperbaharui ilmu-ilmu keagamaan Islam (Ulum al-din). Baik dari segi materi, apalagi teori, metode dan pendekatannya. Kesulitannya berlipat kali dibandingkan dengan keilmuan lainnya, karena agama dianggap dan diyakini kuat oleh umat beragama hanya sebagai doktrin dan dogma yang bersifat tidak dapat dikritik, dipersalahkan, diperbaiki (non-falsifiable). Ini pangkal kesulitannya. Sulit sekali dijelaskan kepada guru-guru dan dosen agama, apalagi yang tidak berprofesi sebagai guru dan dosen agama, seperti aktivis sosial-keagamaan, politisi, elit agama, pegiat dakwah, pimpinan dan tokoh organisasi keagamaan, lebih-lebih yang pola pikir dan cara kerjanya mirip-mirip 
milisi-militan-ekstrim bahwakeilmuan agama (Ulum al-Diin), sesungguhnya, bukanlah agama itu sendiri.Keilmuan agama bukanlah dogma.

Keilmuan agama adalah keilmuan pada umumnya, yang disusun oleh manusia (Muslim) pada jamannya. Oleh karenanya, tidaklah bersifat sakral (Qabilun li-niqasy wa al-al-taghyir). Sama sulitnya menjelaskan perbedaan antara "wahyu" dan "penafsiran atau pemahaman manusia terhadap wahyu".Penafsiran terhadap wahyu bukanlah wahyu itu sendiri. Umumnya, masih sering dipahami bahwa penafsiran manusia terhadap wahyu adalah sederajat bahkan sama dengan wahyu itu sendiri. ${ }^{15}$ Memang disinilah letak core atau jantung analisis dan ijtihad keilmuan. Jantung analisis filsafat keilmuan agama.Oleh karenanya, dapat dipahami mengapa para penganut agama-agama, terlebih lebih golongan elitnya, seringkali menunjukkan corak dan sikap keberagamaan yang emosional, untuk tidak menyebutnya temperamental, kaku dan rigid, tidak terbuka, defensif, apologetik, kurang komunikatif. Tidak boleh dan tidak suka dikritik. Umumnya para pemeluk agama tidak tahan kritik, mudah tersinggung, emosional dan menunjukkan sikap tidak suka terhadap orang atau kelompok lain yang berbeda lantaran tugas berat yang diembannya untuk melindungi kepentingan diri dan kelompok dari kritikan dari luar.

Dalam melakukan kerja ijtihad yang baru, Kalam, Fikih dan Dakwah Sosial kontemporer, seperti yang sering saya utarakan, perlu mempertimbangkan ulang tiga prinsip dasar pola budaya berpikir keagamaan Islam - yang menyatu dalam gerak melingkar-sirkular - yaitu: hadarah al-nash (pola pikir keagamaan Islam yang dilandasi oleh budaya nash atau teks-bayani), hadarah al-ilm (pola pikir keagamaan yang ditopang oleh evidence-based of thought, ilmu-ilmu yang berdasarkan pada data-data empirik, rasioburhani ) dan hadarah al-falsafah (pola pikir keagamaan yang berlandaskan pada etik-transformatiffilosofis atau critical philosophy). Hadarah al-nashdalamijtihad Fikih, Kalam dan Dakwah Sosial modern tidak bisa lagi berdiri sendiri terlepas dari hadarah al-ilm dan hadarah al-falsafah. Begitu pula sebaliknya. Itulah mulitidisiplin, pluridisiplin bahkan transdisiplin dalam konstruk falsafah keilmuannya. Monodisiplin hampir-hampir tidak dapat menjelaskan apa-apa kecuali pada wilayah yang sangat sempit. Berpikir in-box adalah tipikal corak berpikir monodisiplin. Tidak terlintas untuk berpikir yang bercorak out of box, lintas keilmuan, selain yang bercorak in-box. Tiga entitas ini tidak boleh lepas dari yang satu dan lainnya. Jika budaya pikir keilmuan (badarah al-ilm), misalnya, tidak berhubungan dan menyapa dua entitas yang lain maka ujungnya akan berpaling dari realitas dan cenderung tidak berpihak kepada akhlak dan moralitas, dan begitu seterusnya. Ijtihad dalam Kalam, Falsafah, Fikih dan Dakwah Sosial modern dan posmodern perlu mempertimbangkan tiga budaya berpikir keagamaan Islam sekaligus, yang akarnya telah berkembang dalam budaya Muslim sejak era klasik tersebut.

Menurut Jasser Auda, dalam mengembangkan budaya berijtihad, Kalam, Falsafah, Fikih dan Dakwah Sosial modern, lebih-lebih posmodern, harus memiliki world view yang terbuka (Openness). Terbuka dan bersedia menerima masukan dari ilmu-ilmu lain, dan bahkan harus mampu memperbaharui, memperbaiki dan mengoreksi diri sendiri (self-renewal). Tidak hanya itu, pemikiran keagamaan Islam kontemporer perlu berpikir yang bernuansa multidimensi. ${ }^{16}$ Berpikir dengan pola oposisi biner (binary opposition), hitam-putih, kafir-muslim, surga-neraka, qat'iydan dzanny terlalu menyederhanakan persoalan. Masih banyak pilihan lain selain kedua pilihan yang sifatnya binary dan

${ }^{15}$ Pemikiran Abdul Karim Sorous tentang 'Contraction and expansion of religious knowledge", dikutip dari buku Clinton Bennett, Muslims and Modernity: An Introduction to the issues and debates, (London: Continuum, 2005), h. 122..

${ }^{16}$ Jasser Auda, Maqasid al-Shari'ah as Philosophy of Islamic Law: A Systems Approach, London: The International Institute of Islamic Thought, 2008, h.201 dan 211. Jasser Auda tidak seluruhnya menolak pola pikir postmodernisme, namun ia memberi catatan kritis terhadap corak berpikir ini. Ia lebih suka menekankan sisi multidimensionalitas pola dan cara berpikir posmodernitas. 
contradictory. Berpikir multidimensi adalah pengganti corak berpikir oposisi biner. Salah satu ciri corak berpikir posmodernitas adalah sifatnya yang multidimensional, yakni selalu mempertimbangkan berbagai dimensi yang mengitari persoalan yang sedang dihadapi atau dibahas. Manusia beragama perlu dilatih dan terlatih untuk mengkaitkan persoalan agama dengan ekonomi, sosial, budaya, psikologi, seni, medis, filsafat, sains dan begitu seterusnya. ${ }^{17}$ Sikap keilmuan keagamaan yang tertutup dari berbagai kontak dengan keilmuan lain akan menyebabkan keilmuan Fikih, keilmuan Kalam, keilmuan Dakwah atau Ulum al-din pada umumnya tidak dapat berkembang. Tidak sesuai dengan konteks zaman. Sangat boleh jadi akan terperangkap pada corak berpikir era abad pertengahan, era skolastik-pre-scientific, atau akan mengulang kembali apa yang telah terjadi di era pertengahan, yaitu ortodoksi. Jika tidak ingin kembali pada era pertengahan, maka hasil ijtihad harus selalu terbuka untuk menerima hal-hal baru yang lebih baik dalam kehidupan manusia di dunia ini. Inilah semangat Kalam, Falsafah, Fikih, Pendidikan dan Dakwah Sosial di alam modern dan posmodern.

\section{Fikih Perempuan (Fiqh al-nisa' al-mu'asir)}

Bukan Kalam, Falsafah, Fikih, Pendidikan dan Dakwah Sosial "modern" dan lebih-lebih "postmoderen", jika tidak atau belum menyentuh dan memasukkan persoalan perempuan dari perspektif sosiologis. Fikih perempuan (Fiqh al-nisa) yang baru telah memasukkan di dalam analisis pembahasannya faktor keberhasilan program pendidikan untuk semua (education for all; coeducation) yang diikuti oleh perempuan, selain laki-laki. Sosok wanita dilihat dari berbagai perspektif. Fikih, Kalam, Pendidikan dan Dakwah lama umumnya lebih melihat wanita atau perempuan dari perspektif biologis (haid atau menstruasi, najis (air seni) mughaladhah atau mukhaffafah, masa tenggang iddah, suara wanita termasuk aurat) dalam hubungannya dengan peribadatan atau ritual. Sedangkan Kalam, Falsafah, Fikih, Pendidikan dan Dakwah Sosial Islam modern lebih melihatnya dari perspektif sosiologis, yakni peran sosial wanita dalam kehidupan publik di tengah masyarakat luas. Tidak hanya perspektif sosiologis, tetapi juga antropologis, psikologis, politik, hukum, budaya, seni dan begitu seterusnya. Dari sini lalu muncul analisis tentang wanita yang membedakan antara dua perspektif, perspektif sex (biologis) dan sosiologis (gender). ${ }^{18}$

Keberhasilan pendidikan (the rise of education), khususnya untuk wanita, telah membuka kemungkinan cara melihat baru dan bahkan kesadaran baru tentang peran sosial perempuan dalam masyarakat. Jika era pra- modern, bahkan era pra-scientific, kehidupan publik seolah-olah hanya milik pria, sekarang perbincangan masalah wilayah publik juga perlu melibatkan wanita. Wanita tidak mau lagi hanya dikategorikan sebagai "konco wingking" (domestic area). Wanita juga punya konsep bagaimana mengelola ruang dan kehidupan publik bersama-sama pria. Pada era sekarang mereka juga menuntut untuk dipenuhi hak-haknya dalam kehidupan publik (public area). Kepemimpinan sosial-politik dan profesi apapun rupanya juga harus share antara pria dan wanita. Keberhasilan pendidikan telah mengantar pada perubahan sosial yang sangat cepat. Bahkan tugas alamiah wanita untuk melahirkan anak, sekarang tidak dapat lagi dilihat sebagai tugas alamiah-biologis begitu saja. Dalam perspektif sosiologis, tugas alamiah tersebut dapat diangkat ke atas, ke tingkat yang lebih tinggi, yaitu apa yang

\footnotetext{
${ }^{17}$ Ebrahim Moosa, "Introduction”, dalam Ebrahim Moosa (Ed.), Revival and Reform in Islam: A Study of Islamic Fundamentalism Fazlur Rahman, (Oxford: Oneworld Publications, 2000), h. 28.

${ }^{18}$ Mariam Ait Ahmad, al-Mar'ah al-muslimah baina tahaddiyat al-tamkin wa mustaqbalah al-tanmiyah, (al-Qahirah: Dar al-Salam, 2013); Nasr Hamid Abu Zaid, Dawair al-Khauf: Qira'ah fi Khitab al-mar'ah, (Bairut: al-Hamra', 2000); Muhammad Sharur, Nahw usulin jadidah li al-fiqh al-islamiy: Fiqh al-Mar'ah (al-Wasiyyah-al-Irts-al-Qawwamah-al-Ta'addudiyyah-al-libas), (Damaskus: al-ahali li altiba'ah wa al-nasyr wa al-tauzi', 2000).
} 
disebut dengan hak-hak reproduksi. Jika dahulu tugas tersebut hanya dilihat secara alamiah (nature), sekarang tidak begitu lagi. Pemenuhan hak-hak reproduksi adalah mandat kemanusiaan dan tugas pemerintah dan masyarakat luas untuk memenuhinya. Namun, di lapangan tidak mudah untuk memenuhinya, karena ternyata pemahaman ini sangat terkait dengan banyak hal, dan utamanya terkait dengan budaya (nurture). Sedang dalam wilayah budaya (nurture), peran pemahaman dan penafsiran agama sangat luar biasa besar pengaruh dan hegemoninya.

Banyak hal lain yang terkait dengan hak-hak reproduksi, sejak dari batas usia perkawinan ( 9 , 16, 18 atau 21 tahun), angka kematian ibu, keluarga berencana, gender-based budget, politik anggaran pemerintah pusat dan daerah untuk mengurangi angka kematian ibu, keluarga berencana (Family Planning) dan begitu seterusnya. Belum lagi menyentuh problem keluarga dan sosial dari poligami dan monogami. Dari situ, kemudian mengemuka ke atas permukaan dan menjadi gerakan sosial yang luas. Keberhasilan pendidikan telah membentuk kesadaran baru baik dari kalangan pria maupun dari kalangan perempuan. Setelah perempuan berhasil menamatkan pendidikan dasar, menengah, atas, apalagi sampai menyelesaikan program akademik pada jenjang S 1, 2 dan lebih-lebih S 3, maka muncul aspirasi, tuntutan, penafsiran dan pemahaman atau singkatnya "tafsir baru" keagamaan yang terkait dengan permasalahan wanita di tengah masyarakat Muslim di seluruh dunia.

Problem sosiologi yang disebut sebagai fenomena marginalisasi dan subordinasi peran perempuan dalam kehidupan sosial, politik (kepemimpinan politik), ketenagakerjaan (upah pekerja wanita, cuti hamil, menyusui anak), keagamaan (poligami-monogami; hakim wanita; saksi; warisan; perwalian; jilbab) dan begitu seterusnya yang selama ini dirasakan dalam hegemoni budaya patriarki mulai diungkap ke permukaan, tidak hanya sebatas wacana tetapi gerakan. Tak terhitung lembaga swadaya masyarakat di tanah air yang membidangi penguatan hak-hak perempuan. ${ }^{19}$ Bahkan pemerintah pun juga mempunyai kementrian khusus yang membidangi pemberdayaan perempuan danperlindungan anak. Sama halnya, akan muncul aspirasi adanya beban ganda (double burden) yang dirasakan utamanya oleh para wanita pekerja, kerja di dalam rumah dan di luar rumah. Bahkan di dalam rumah (wilayah domestic) pun dirasakan adanya semacam double burden juga. Tak pelak, semua ini berhadapan langsung dengan corak pemahaman laki-laki tentang isu-isu ini ketika berada di rumah dan masyarakat. Semua ini akhirnya berujung dan berhadapan dengan world view atau tafsir religiososiologis lama yang dikonstruk oleh para penafsir/mufassir atas nash-nash al-Qur'an dan al-Hadits. ${ }^{20}$ Muncullah analisis yang tajam terhadap nash-nash hadits dan penafsirannya yang terkait dengan wanita. Dan ternyata nash-nash yang berkait dengan wanita sangat banyak, karena wanita adalah bagian tak terpisahkan dari kehidupan itu sendiri. Dalam analisis gender, ditemukan kategori hadis baru yang belum ditemukan dalam kitab hadis yang ada yaitu apa disebut dengan hadis-hadis misoginik, yaitu hadis-hadis sosial yang kurang menghargai wanita sebagai manusia yang otonom dan mempunyai harkat dan martabat kemanusiaan sama seperti yang dimiliki oleh laki-laki.

Kalam, Falsafah, Fikih, Pendidikan dan Dakwah Sosial modern tidak bisa tidak pasti bersentuhan dengan hal ini semua. Para penafsir yang memiliki kesadaran baru ini, sebutlah mereka sebagai para fuqahaatau mutakallimun baru, terdorong untuk melakukan penelitian, kajian ulang terhadap kitab-kitab tafsir terdahulu yang terkait dengan penafsiran dan pemahaman para penafsirnya

${ }^{19}$ Pemikiran ndan tafsiran baru para penulis dan peneliti dari UIN Sunan Kalijaga dapat di rujuk pada buku yang diedit oleh Siti Ruhaini Dzuhayatin, et. all., Menuju Hukum Keluarga Progressif, Responsif Gender dan Akomodatif Hak. Anak, (Yogyakarta: Suka Press, PSW UIN Sunan Kalijaga dan The Asia Foundation, 2013).

${ }^{20}$ Muhammad al-Ghazali, al-Sunnah al-Nabawiyyah baina abl al-fiqh wa abl al-hadits, (Beirut: Dar al-syuruq, 1989), h.35-61. 
tentang wanita saat itu dan kemudian di perbandingkan dengan kebutuhan tafsir baru yang lebih sesuai dengan perubahan sosial dan tuntutan zaman saat ini. Pembahasan dan diskusi tentang agama dan perempuan di Indonesia - agama dalam arti pemahaman Fikih dan Kalam - termasuk yang relatif paling maju dan berkembang dalam Fikih Sosial dan Kalam Sosial saat sekarang ini, sejak dimulai perbahasannya tahun 1990an.

\section{Inter-cultural dan inter-faith dialog (al-biwar; al-ta'ayus al-silmy)}

Dialog atau al-hiwar merupakan salah satu unsur yang tidak terpisahkan dalam Kalam, Falsafah, Fikih, Pendidikan dan Dakwah Sosial kontemporer yang seringkali masih dianggap kurang penting. Dialog disini tidak lagi dipahami dalam bentuk perdebatan (jadal) yang antara masing-masing pihak dalam debat mempertahankan keyakinannya dan ideologinya masing-masing (argumentum ad hominem; demonstration of the believed truth), melainkan dialog yang ingin mencari solusi masalah-masalah kemanusiaan bersama (insaniyyah), bukan masalah keyakinan atau ideologi. Dialog disini adalah dialog intelektual atau dialog ide untuk menemukan solusi terbaik bagi permasalahan kemanusiaan universal. Dialog disini merupakan dialog untuk mencari kebenaran dan keadilan, bukan mencapai kemenangan dan mempertahankan superioritas masing-masing peserta dialog. Dialog bukan dan tidak bertujuan untuk memindah atau mengganti agama yang telah diyakininya (konversi) partner dialog, apalagi untuk mencela atau menganggap rendah keyakinan pengikut agama lain.

Setidaknya ada tiga persoalan, yang dapat didialogkan dalam Fikih, Kalam dan Dakwah modern, dalam konteks dialog antar budaya dan antar agama/iman . Pertama masalah kemanusiaan universal (al-insaniyyah), di antaranya berkaitan dengan masalah pendidikan, kebodohan, keterbelakangan, kesehatan, kemiskinan, kekerasan atas nama agama, dan lain sebagainya. Kedua, masalah kebudayaan (al-hadharah) di antaranya adalah bahasa, kebiasaan, adat-istiadat, life style, feeling of the people dan lain sebagainya. Ketiga, masalah hak asasi manusia, seperti kesempatan untuk hidup (al-hayah), kebebasan, kemerdekaan, kesejahteraan dan lain-lain. Ketiga hal ini mendapat porsi yang cukup vital dalam dialog-dialog Fikih, Kalam dan Dakwah Sosial modern. Bukanlah Kalam, Falsafah, Fikih, Pendidikan dan Dakwah Sosial modern jika dalam sepanjang perkuliahan yang dilaluinya, baik di program S 1, S 2 apalagi S 3 di lingkungan UIN, IAIN maupun STAIN jika belum pernah menyentuh persoalan dialog antar budaya dan agama yang terbuka dan mencerahkan.

Dalam perkuliahan di kelas, saya selalu menekankan arti penting dialog dalam Kalam dan Falsafah Islam modern, yang titik tekannya tidak mencari kemenangan kelompok atau madzhab, keyakinan atau organisasi keagamaan tertentu (usul al-madzhab), melainkan dialog untuk mencari kebenaran dan keadilan universal (al-maslahah al-'amab) yang memiliki tujuan, antara lain: (1). Untuk saling mengenal (at-ta'aaruf); (2) Untuk saling mengerti (at-tafaahum); (3) Untuk saling mengasihi (attaraabum); (4) Untuk membangun solidaritas (al-tadhamun); (5) Untuk hidup bersama secara damai (at-ta'ayusy al-silmy) $)^{21}$

Pentingnya dialog antar budaya dan agama di era kontemporer ini dipertegas dengan ditandatanganinya surat terbuka (Open Letter) kepada Paus Benedictus XVI di Vatikan oleh 138 Muslim (intelektual, scholars, ulama, mufti). Surat terbuka ini kemudian lebih dikenal dengan sebutan $A$ Common Word between Us and You (ACW) (terjemahan dari ayat al-Qur'an Ta'alau ila kalimatin sawa' bainana wa bainakum). Para penandatangan surat terbuka tersebut menggarisbawahi pentingnya hidup

${ }^{21}$ Muhammad al-Talbi, Tyalu al-Allah: Afkear Jadidah fi 'alaqah al-Muslim bi nafsibi wa bi al-akharin, (Tunisia: Dar siras li alnasyr), 1992; Mariam Ait Ahmad, Jadaliyyatu al-Hiwar: Qira'ah fi al-Khitab al-Islamiy al-mu'asir, 2011. 
yang rukun, damai dan harmoni antara Muslim dan Kristen dimanapun mereka berada, karena baik al-Qur'an maupun Injil sama-sama menekankan perlunya mencintai Tuhan (love God) dan mencintai tetangga (Love Neighbour) sekaligus. Mereka sangat prihatin, jika keduanya, penganut Islam dan Kristen, tidak dapat menjalin hubungan yang harmonis, saling bertegur sapa, saling bekerja sama dengan tulus, mengingat bahwa $55 \%$ penduduk dunia adalah Muslim dan Kristen (Muslim 23\%; KristenKatolik $32 \%$ dan pengikut agama-agama lain $45 \%$ ). Artinya dimanapun di belahan dunia ini, jika ada orang Muslim disitu ada juga orang Kristen dan begitu pula sebaliknya, dimana ada orang Kristen disitu juga ada orang Muslim. Perdamaian dunia (world peace) amat ditentukan oleh pola hubungan sosial-politik pengikut kedua agama ini. ${ }^{22}$ Suka atau tidak, a greater inter-faith interaction, saling dekatnya hubungan sosial antar pengikut agama-agama, sangat mewarnai kehidupan umat beragama di era global sekarang ini. Oleh karenanya, diperlukan konsep ilmu Fikih, Kalam, Pendidikan/Tarbiyah dan Dakwah baru serta pola, metode pengajaran atau perkuliahan serta kualitas dosen pengajar atau gurunya yang excellent,yang memiliki religious literacy yang lebih dari cukup, yang dapat mensupport dan mendukung tercapainya al-ta'aruf, al-tafaabum, al-taraabum, al-tadhamun dan al-ta'ayus al-silmi antara Muslim dan Kristen dimana pun berada dan juga dengan pengikut agama-agama yang lain.

\section{Fikih dan Dakwah Sosial}

Fikih sosial, yaitu fikih yang dibangun atas dasar hubungan yang setara antara individu atau kelompok di dalam masyarakat. Semangatnya adalah menjadikan fikih tidak hanya sebagai hukum 'agama' (hukum fikih 'ibadah maupun fikih jinayah) akan tetapi menjadikannya sebagai kritik sosial, agen perubahan sosial, penggerak perubahan yang positif dalam masyarakat. Fikih sosial, termasuk di dalamnya Kalam, Falsafah, Pendidikan dan Dakwah Sosial, lebih peka terhadap masalah-masalah sosial dan lingkungan dan lebih ramah terhadap budaya lokal serta peradaban universal-kemanusiaan pada saat yang sama.

Yang membedakan antara fikih biasa atau ilmu fikih yang selama ini secara umum dipahami danfikih sosial antara lain adalah karena fikih sosial memasuki wilayah dan memverifikasi persoalan pemahaman keagamaan yang tidak lagi hanya terbatas antara apa yang disebut atau dikategorikan dalam keilmuan ushul al-figh sebagai yang pokok dan cabang, bukan sekedar persoalan ushul dan furu' atau qat'iy dan dzanniy dalam tradisi berpikir Fikih, Kalam dan Falsafah di dalam memahami nash (alQur'an dan al-Hadits) di lingkungan Ulum al-din. Fikih, Kalam, Falsafah dan Dakwah Sosial, selain memahami hal tersebut, juga mengenal dengan baik mana sisi al-Tsawabit (yang diyakini dan dianggap 'tetap') dan sekaligus sisi al-mutaghayyirat (yang diyakini dan dianggap 'berubah-ubah'); keterhubungan antara yang universal danparticular, antara one dan many, antara subjektif dan objektif, antara Kulliyyat dan Jusiyyat dalam tradisi falsafah. Hal tersebut dilakukan dengan menggunakan metode Maqashid al-syari'ah (tujuan utama dari pensyari'atan agama), bukan sekedar 'illah fiqhiyyah. Dari perjumpaan yang altsawabit dan al-mutaghayyirat tersebut, dapat dipahami bahwa Fikih dan Dakwah Sosial, spirit dan pola pikir keagamaannya tidak lagi melupakan dan meninggalkan sisi universal ('alamiyyah) kemanusiaan. Meminjam bahasa Jasser Auda, Fikih Sosial modern menekankan juga sisi general maqasid, dan tidak lagi hanya semata-mata menekankan pada sisi specific, apalagi yang hanya partial maqasid. ${ }^{23}$

${ }^{22}$ Shaykh Ali Goma'a, "A Common Word Between Us and You”: Motives and Applications", dalam Waleed el-Ansary dan David K. Linnan (Ed.), Muslim and Christian Understanding: Theory and Application of "A Common Word", (New York: Palgrave McMillan, 2010), h. 15-19; juga artikel-artikel lain yang ditulis oleh Seyyed Hossein Nasr, William O. Gregg dan lain-lain dalam buku tersebut.

${ }^{23}$ Jasser Auda, Maqasid al-Shariah as Philosoby of Islamic Law: A Systems Approach, (London: The International Institute of Islamic Thought, 2008), h. 5-8. 
Fikih sosial adalah sebuah usaha pengaktualisasian fikih klasik melalui upaya aktualisasi keseluruhan nilai yang ada di dalamnya untuk dioptimalkan dalam pelaksanaannya dan diserasikan dengan tuntunan makna sosial yang terus berkembang. Tujuan pokok fikih sosial adalah membentuk sebuah konsep dan cara pandang fikih yang berdimensi sosial, atau fikih yang dibangun dengan melihat peran individu atau kelompok dalam proses bermasyarakat dan bernegara (negara bangsa; nationstates) secara universal.

Fikih sosial bisa juga dimaknai dengan cara pandang dalam melihat perubahan sosial di abad postmodernisme dari sisi fikih (hukum Islam). Saat ini, persoalan terbesar umat manusia adalah munculnya berbagai persoalan sosial kemasyarakatan dan berbagai persoalan lainnya yang menyelimuti kehidupan manusia itu sendiri. Untuk mengantisipasi perkembangan sosial yang demikian pesat saat ini, perangkat-perangkat hukum yang telah ada, disamping al-Qur'an dan as-Sunnah, para ulama fikih (fuqoha) dan pemimpin Muslim di seluruh dunia diharapkan tanggap serta ditantang untuk melakukan ijtihad yang segar (fresh ijtihad) guna menyelesaikan masalah-masalah sosial dan hukum kenegaraan yang lahir akibat perubahan atau perkembangan sosial yang sangat cepat dalam masyarakat Islam dimana pun mereka berada. ${ }^{24}$

Secara paradigmatik, persoalan-persoalan yang muncul di masyarakat modern dan posmodern yang menimbulkan persoalan hukum harus disikapi secara kritis dan bijak sehinggaijtibad(pengambilan keputusan hukum dan atau fatwa) nantinya oleh para fuqaha dan pemimpin Muslim lainnya dapat memberikan ketenangan, perlindungan dan ketentraman kepada ummat. Tidak hanya internal umat Islam, tapi juga dirasakan nyaman dan aman bagi pengikut agama lain dan budaya lokal lainnya. Bagaimana mereka dapat merasa comfortabledalam beragama dan bernegara sekaligus ketika mereka memasuki dan bergumul dengan permasalahan perubahasan sosial yang begitu cepat di era modernitas dan posmodernitas.

Pada prinsipnya, tujuan syari'at Islam dalam ajaran fikih ialah penataan kehidupan manusia, baik duniawi maupun ukhrawi, kehidupan individu, bermasyarakat dan bernegara. Bahkan juga sebagai warga dunia (world citizenship) di era global seperti saat sekarang ini. Syari'at Islam mengatur hubungan antara manusia dengan Allah yang dalam fikih menjadi komponen ibadah, baik sosial maupun individual, muqayyadah (terikat oleh syarat dan rukun) maupun muthlaqah (tidak terikat). Ia juga mengatur hubungan dan tata cara keluarga, yang dirumuskan dalam komponen munakahat. Dalam pergaulan yang menjamin ketentraman dan keadilan, ia juga punya aturan yang dijabarkan dalam komponen jinayah, jihad, dan qadla. Namun, para fuqaba dan mutakallimun generasi baru era sekarang, dalam konteks kehidupan global sekarang, harus selalu diingatkan agar aturan-aturan yang sifatnya partial dan specific maqasid ini, jangan sampai melupakan sisi general maqasid.

Pemecahan problem sosial berarti merupakan upaya memenuhi tanggung jawab kaum muslimin atas kewajiban mewujudkan kesejahteraan atau kemaslahatan umum di muka bumi, baik di tingkat lokal, regional, nasional maupun internasional. Dalam hal ini, kemaslahatan umum (al-maslahah al'ammah) kurang lebih adalah kebutuhan nyata masyarakat dalam suatu kawasan tertentu untuk menunjang kesejahteraan lahiriah maupun batiniyyah nya. Baik kebutuhan itu berdimensi dharuriyat atau kebutuhan dasar (basic need) yang menjadi sarana pokok untuk mencapai keselamatan agama, akal pikiran, jiwa, raga, nasab (keturunan) dan harta benda, maupun kebutuhan hajiyat (sekunder) dan kebutuhan yang berdimensi tahsiniyyat atau pelengkap (suplementer).

${ }^{24}$ Termasuk permasalahan baru yang dialami dan dirasakan oleh umat Islam -selama hampir 50 tahun terakhir - yang tinggal di wilayah mayoritas Kristen seperti di negara-negara Eropa, Australia dan Amerika Serikat. Yvonna Yasbeck Haddad, Muslims in the West: From Sojourners to Citizens, (Oxford: Oxford University Press, 2002). 
Secara singkat dapat dirumuskan, paradigma fikih dan dakwah sosial didasarkan atas keyakinan bahwa fikih dan dakwah harus dibaca dalam konteks pemecahan dan pemenuhan tiga jenis kebutuhan manusia di atas yaitu primer, sekunder, dan tersier dalam konteks kehidupan komunitas lokal, regional, nasional maupun internasional. Fikih sosial bukan sekedar alat sebagaimana cara pandang fikih lama, yang lazim kita temukan, tetapi fikih sosial juga menjadikan fikih sebagai paradigma pemaknaan sosial yang lebih luas, yang sampai menjangkau general maqasid (Hak asasi manusia, Kebebasan beragama, berpendapat, berserikat, keadilan bagi seluruh umat manusia), tidak hanya terfokus pada partial dan specific maqasid yang umum dipelajari dan ditekankan dalam Ushul fiqh.Ada sedikit pergeseran paradigma dan perluasan ruang lingkup maqasid yang dirumuskan pada era klasik dan maqasid yang dirumuskan pada era kontemporer ${ }^{25}$.

Krisis kemanusiaan muncul disebabkan karena kurangnya kajian kemanusiaan universal dalam literatur lama. Bukan berarti kajian manusia sama sekali tidak ada dalam khazanah klasik, misalnya, ilmu usul al-din (pokok-pokok agama) yang pada dasarnya memperlihatkan studi tentang manusia, eksistensi manusia, masyarakat manusia, namun jika tanpa dibarengi kajian metodologi yang independen (al-maqasid al-ammah; general al-maqasid) justru akan mengeluarkan manusia dari esensinya. Pembahasan akan mudah terjatuh pada wilayah "subjektif", tetapi kurang memperhatikan wilayah “objektif” kemanusiaan. Begitu pula, eksistensi manusia dapat ditemukan di dalam setiap pengetahuan dan pemikiran, namun ia seringkali telah ditutup oleh selubung-selubung bahasa, ideologi, mitos, hukum dan aturan perundang-undangan.

Inilah permasalahan yang ada saat ini yaitu krisis kemanusiaan dan keberagamaan. Tugas para pencinta ilmu-ilmu keagamaan Islam yang baru adalah bagaimana menghilangkan selubung-selubung "subjective", "particular", "juz'iyyat" tersebut dan masuk menembus ke jantung sosok kemanusiaan yang genuine,"objective", "universal”, "general". Inilah dilema perumusan persoalan hubungan antara general maqasid dan specific dan atau partial maqasid yang telah disinggung di atas. Untuk memasuki wilayah general maqasid, para ilmuan dan agamawantidak bisa tidak perlu dibantu dengan seperangkat alat analisis keilmuan dan kefilsafatan. Dengan cara pandang tadi, Kalam modern yang mendasari Dakwah modern, menginginkan Muslim mentransformasikan peradaban mereka dari fase mitos lama, ke fase dogma dan doktrin dan dari keduanya itu berpindah ke fase kemanusiaan baru berlandaskan analisis keilmuan, dan mentransformasikan inti kebudayaan dari pengetahuan Tuhan (theocentric) kepada pengetahuan manusia itu sendiri (anthropocentric). Ini tidak mudah mengingat corak pemikiran Fikih/ Kalam dan Falsafah berbeda secara diametrical, seperti yang dinyatakan Josef van Ess, sebagai berikut:

"... The reason for this somewhat disappointing verbalism lies in ontology: many mutakallimuncomprehended things as mere conglomerates of accidents, without any substance of their own; Aristotelian definition, however, presupposes an antology of matter and form. Definition as used by the mutakallimun usually does not intend to lift individual phenomena to a higher, generic category; it simply distinguishes them from other thing (tamyiz). One was not primarily concerned with the problem how find out the esssence of a thing, but rather how to circumcribe it in the shortes way so that everybody could easily grasp what was meant. This, however, could already be attained by verbal definitions; most theologians of the early centuries seem to have contended themselves with this variety". ${ }^{2}$

Dengan bertambah dan berkualitasnya pemikiran, hasil penelitian dan kajian-kajian baru yang dilakukan oleh Muslim scholars sendiri, kesulitan-kesulitan ini lambat laun akan dapat teratasi, dengan catatan para peniliti dan dosen perguruan tinggi agama di bawah Kementrian Agama bekerja lebih

${ }^{25}$ Jasser Auda, Maqasid al-Shariah, h. 21-24.

${ }^{26}$ Josef van Ess, "The Logical Structure. 
keras dan serius lagi melakukan telaah literatur dan penelitian yang hasilnya dapat dijadikan rujukan untuk perbaikan referensi, metode dan pendekatan dalam pengajaran dan perkuliahan filsafat ilmuilmu keagamaan Islam. Tanpa upaya ini, maka sinyalemen yang diungkapkan oleh Nidhal Guessoum di atas akan terbukti dengan sendirinya.

\section{Fikih dan Dakwah Universal}

Jika pada era klasik, Fikih (hukum) dan Kalam (teologi) dirumuskan hanya untuk kepentingan lokal, ad hoc dan parsial, pada Kalam modern terdapat tuntutan untuk merumuskan fikih dan dakwah yang universal (fikih dan dakwah yang dapat diterima oleh semua kalangan, tidak hanya untuk umat Islam melainkan juga dengan non-Islam). Fikih universal maksudnya adalah fikih yang mengandung nilai-nilai kemanusiaan universal, seperti solidaritas, toleransi, persaudaraan, keadilan antar umat manusia, dan lain sebagainya.

Hubungan antar negara dalam fikih politik (Fiqh al-siyasah) abad tengah dirumuskan dengan istilah dar al-Islam dan dar al-harb, termasuk istilah kafir harbi dan kafir dzimmi, dapat menyebabkan percekcokan, perselisihan tiada henti dan tidak jarang yang mengantarkan sampai ke peperangan antar pengikut agama. Maka, untuk menghentikan percekcokan, perselisihan dan peperangan antar agama di era global saat ini polarisasi dan kontestasi tersebut perlu dikurangi, bahkan perlu dihapus. Sekarang umat manusia di berbagai negara sudah banyak yang sadar akan pentingnya perdamaian dan persahabatan untuk mengembangkan kehidupan menjadi lebih baik, tidak pandang apa agamanya. Semua bisa bersatu untuk mencapai kehidupan yang lebih baik. Islam sangat menganjurkan perdamaian. Tidak ada dalam al-Qur'an ataupun hadis yang menjelaskan kepada umat Islam untuk melakukan penyerangan terhadap pengikut agama lain yang mau hidup damai berdampingan dengan Islam, malah Islam memerintahkan umatnya untuk terlebih dahulu mengulurkan tangan dalam rangka menciptakan perdamaian di dunia (QS. Al-Anfal $\{8\}$ : 61, QS. At-Taubah $\{9\}:$ 6). Islam tidak membolehkan umatnya untuk mengadakan kerusakan, seperti berperang, kecuali diserang terlebih dahulu (QS. Al-Baqarah \{2\}: 190). Namun, meskipun mendapat izin berperang, Islam masih menganjurkan bahwa jalan damai lebih baik ketimbang jalan peperangan (QS. Al-Fushshilat $\{41\}$ : 34, QS. Al-Hujuraat \{49\}: 9-10). Itulah luhurnya sisi normatif dan scriptural dari ajaran Islam. Namun, pada sisi historis, ternyata masih banyak yang menyedihkan. Umat Islam di tengah kemajuan dan kesejahteraan bangsa lain, masih menyaksikan perbuatan keji seperti penganiayaan, pembunuhan, penculikan dan pertumpahan darah, genocide, yang tak berkesudahan seperti yang terjadi di Afrika Tengah, Nigeria dan beberapa wilayah di Timur Tengah. Arab Spring belum dapat dikatakan usai. Gerakan Ikhwan al-Muslimin belakangan malah dinyatakan sebagai gerakan terlarang, baik di Mesir - negara asal mula berkembangnya gerakan ini - maupun di Saudi Arabia dan beberapa anggota Dewan Kerjasama Teluk (GCC). Artinya, masih banyak persoalan sosial, apalagi politik yang dihadapi umat Islam di dunia ini. ${ }^{27}$ Belum lagi pergolakan sosial politik di Suria selama 3 tahun terakhir (20112014) menurut laporan PBB, memakan korban tidak kurang dari 191.000 orang.

Islam melarang umatnya untuk melakukan olok-olok dan mencari-cari kesalahan orang lain, karena belum tentu orang lain yang diolok-olok benar-benar jelek, bahkan bisa jadi orang yang mengolok-olok lebih jelek daripada yang diolok-olok. Persoalan lain adanya sifat dengki ini adalah

\footnotetext{
${ }^{27}$ Pascal S bin Saju, “Kekerasan di Luar Batas Seakan Tak Berkesudahan”, Kompas, 9 Maret, 2014, h. 10. Juga tentang “Pro dan Kontra Ikhwanul Muslimin: Ketegangan Meluas di Teluk, Kompas, 9 Maret 2014, h. 10. Lebih lengkap lihat Roel Meijer (Ed.), Global Salafism: Iswlam's New Religious Movement, (London: Hurst \& Company, 2009).
} 
dapat menyebabkan pertikaian antar manusia. Oleh karena itu, sifat dengki sangat dilarang (QS. AlHujuraat $\{49\}$ : 11, QS. Al Hujuraat $\{49\}$ : 12). Bahkan di ruang publik (tafassabu fi al-majalis), umat Islam selalu diminta untuk saling memberi ruang gerak yang luas dan kemudahan bagi orang dan kelompok lain (QS. al-Mujadilah \{58\}: 11). Basis normatif-tekstual ini masih perlu diturunkan ke level praxis di lapangan dengan dukungan ilmu pengetahuan dan penelitian baru di lapangan tentang bagaimana sesungguhnya dan senyatanya umat beragama (Islam) mengantisipasi, mengelola konflik dan resolusi konflik. Hal yang terakhir ini sangat jarang dilakukan oleh umat beragama pada umumnya.

Sekali lagi, Islam sangat menganjurkan umatnya untuk menciptakan kedamaian, tidak hanya di kalangan sendiri, tetapi juga di kalangan seluruh umat manusia. Untuk menciptakan kedamaian, Islam berpijak pada prinsip-prinsip perdamaian, yaitu kasih sayang (mababbab), kebersamaan (ijtimaa'iyah), persamaan (musaawah), keadilan ('adalah), dan persaudaraan (ukhumwah). Fikih universal semacam inilah yang hendak dirumuskan kembali dalam Kalam, Falsafah, Fikih, Pendidikan dan Dakwah modern. Namun anjuran al-Qur'an ini hampir-hampir - untuk sebagian wilayah - masih mengalami jalan buntu dalam alam praksis di akar rumput, karena pemikiran Fikih dan Kalam enggan memperbaiki cara dan metodologi berpikirnya. Egoisme madz̧hab, sektarianisme kelompok atau golongan dan organisasi masih terhitung cukup tinggi. Para peneliti masih mencatat bahwa Social Hostility Indext dalam masyarakat Muslim cukup tinggi. Membuka diri untuk perbaikan metodologi berpikir adalah kata kunci disini. Lagi-lagi, seperti yang terurai di atas, openness (keterbukaan) dan selfrenewal (kemampuan untuk memperbaharui diri) dan multidimensionalitas berpikir keagamaan Islam adalah syarat mutlak untuk menyempurnakan cara dan metode berpikir keagamaan Islam yang baru. Salah satu caranya adalah dengan cara mengenal dan mengadapt, mengadopt cara berpikir filosofis keilmuan baru, karena itu pulalah kuncinya. Berikut kutipan pendapat Jasser Auda ketika menginginkan digunakan al-qiyas al-wasi', sebagai pengganti metode qiyas lama dan juga perlunya menggunakan pendekatan mulitidisiplin di dalam pemikiran hukum Islam:

"Analogical reasoning (qiyas) is another source of legislation' that was re-interpreted from its traditional deductive structure (considering a single case mentioned in the script as a basis for judgement for a new case) to a form of abduction (considering the largest possible number of cases that are related to the topic and deducing general guidelines for judgement). A number of usul revisionists called this new method of qiyas, 'wide analogy' (al-qiyas al-wasi')". 28

\section{Fikih dan dakwah kewargaan.}

Pascakolonialisme berkembang paham nasionalisme. Nasionalisme terbangun bukan hanya atas dasar kesamaan agama (ummah), melainkan juga karena kesamaan nasib, tradisi, adat-istiadat, bahasa, persaudaraan, penerimaan terhadap orang lain yang mau bergabung meskipun berbeda agama, dan lain sebagainya. Nasionalisme (nation-states; al-wathaniyyah) telah memunculkan negara-negara yang merdeka dan berdaulat. Dengan adanya nasionalisme dan negara, secara otomatis juga memunculkan paham kewarganegaraan (citizenship). Umat Islam dan non-Islam saat ini bisa bersatu dalam identitas kewarganegaraan dan setara di depan hukum (equality before law). Isu mayoritas dan minoritas menjadi tidak relevan dalam konteks negara bangsa. Dan istilah dzimmi (golongan minoritas yang dilindungi) pun juga tidak relevan untuk diangkat dalam Kalam, Fikih, Pendidikan dan Dakwah Sosial modern

${ }^{28}$ Jasser Auda, Maqasid al-Shariah, h.179. Jasser menambahkan perlunya pendekatan multidisiplin dalam keilmuan Hukum Islam, jika ingin beranjak dari tradisi keilmuan nya yang lama. "Without incorporating relevant ideas from other diciplines, research in the fundamental theory of Islamic law will remain within the limits of traditional literature and its manuscripts, and Islamic law will continue to be largely "outdated" in its theoretical basis and practical outcomes. The relevance and need for a multidiciplinary approach to fundamental of Islamic law is one of the argument of this book". Jasser Auda, Maqasid al-Shariah, h. xxvi. 
sekarang ini. Termasuk formalisasi syari'ah. Umat Islam saat ini bisa menjadi warga negara Eropa yang mayoritas beragama Kristen. Sebaliknya juga demikian, umat Kristen bisa tinggal di negaranegara mayoritas Islam, sebagai warga negara di negara tersebut.

Dengan demikian, status pertama dalam sebuah negara tidak lagi hanya agama (ummat; religious affiliation), melainkan kewargaan dan kewarganegaraan (citizenship). Semua pemeluk agama yang berbeda-beda mendapatkan hak dan kewajiban yang sama dalam sebuah negara. Konstitusi bernegara (the idea of constitution) lebih mengemuka dan penting didiskusikan dari pada ide negara Islam atau Kristen (theocracy). Hal ini yang dikaji dalam Fiqh siyasah modern dan Kalam modern. Menurut Tariq Ramadan, umat Islam yang hidup dalam sebuah negara tertentu, memiliki hak dan kewajiban yang sama dengan warga negara yang lain. Dengan kata lain, identitas keislaman harus melebur dalam identitas nasional. Istilah yang tepat untuk sebutan penomena demografis yang baru ini bukan lagi Islam in Indonesia, tetapi lebih tepat disebut Indonesian Muslim. Bukan Islam atau Muslim in Europe tetapi European Muslim. ${ }^{29}$ Jika umat Islam tinggal di negara yang mayoritas penduduknya beragama Kristen, karena sudah menjadi warga negara di sana, maka, sebagaimana yang dikatakan Fethullah Gulen, pemikir Muslim dari Turki yang tinggal di Pensylvania, Amerika Serikat, umat Islam harus melupakan statusnya sebagai minoritas dan menganggap dirinya sebagai bagian yang menyatu dengan mayoritas, dalam hal ini adalah mayoritas Kristen.

Analog dengan permasalahan diatas, menarik juga mencermati bagaimana perkembangan Muslim yang tinggal di Indonesia bagian Timur dan Kristen yang tinggal di Indonesia bagian Barat, meskipun keduanya telah berada di bawah payung besar Pancasila dan Negara Kesatuan Republik Indonesia. Namun dari segi tradisi dan budaya tetap saja unik dan spesifik, sehingga masing-masing dituntut untuk mampu beradaptasi dengan baik dengan lingkungan budaya dan kultur setempat. Bahkan saling belajar antara tradisi keberagamaan masing-masing dan bukannya memaksakan tradisi dan budaya agama yang dibawanya dari tempat asal untuk diterapkan di tradisi yang berbeda. Kearifan lokal seperti ini amat penting untuk tata kelola kepemerintahan dan tata pergaulan yang merajut keislaman, keindonesiaan dan kemoderenan. Inilah fikih realitas atau realisme fikih dan bukannya formalisme syari’ah.

Umat Islam dimanapun ia berada, dalam pemahaman Kalam dan Dakwah modern, dituntut untuk melakukan dan memprioritaskan, dalam bahasa Fethullah Gulen, pelayanan (hizmet), pelayanan sosial dan pelayanan pendidikan. Pelayanan disini tidak hanya ditujukan kepada sesama umat Islam, melainkan kepada seluruh umat manusia, tanpa memandang latar belakang agamanya ${ }^{30}$. Inilah yang menjadikan model pendidikan - untuk tidak menyebutnya sebagai dakwah modern - yang dikembangkannya dapat diterima di seluruh dunia. Dan inilah memang yang menjadi tujuan para nabi dan Islam itu sendiri, yaitu pelayanan atau rahmat bagi seluruh alam semesta (QS. Al-Anbyaa' [21]: 107). Hizmet atausocial services dalam bidang pendidikan dapat diterima di berbagai bangsa dan negara di dunia, lebih dari 100 negara di dunia. Cermin dan wajah Muslim kosmopolit yang dulunya sulit dicari sekarang mulai tampak sosok dan profilnya dalam karya dan gerakan pendidikan yang terinspirasi oleh pemikiran kosmopolit Fethullah Gulen ${ }^{31}$.

${ }^{29}$ Tariq Ramadan, Western Muslims and the Future of Islam, (Oxford: Oxford University Press, 2004). Di Indonesia dikenal istilah "pribumisasi Islam", dakwah kultural, "Islam Yes, Partai Islam No" dan lain sebagainya.

${ }^{30}$ Thomas Michel, "Gulen as Educator”, dalam M. Hakan Yavuz dan John L. Esposito (Ed.), Turkish Islam and the Secular State: The Gulen Movement, (New York: Syracuse Uiniversity Press, 2003), h. 69-84, khususnya 70.

${ }^{31}$ Robert A. Hunt and Yuksel A. Aslandogan (Ed.), Muslim Citizen of the Globalized World: Contribution of the Gulen Movement, (New York: The Light Inc. \& IID Press, 2006); Juga Md. Maimul Ahsan Khan, Introducing Fethullab Gulen to Bengal and Beyond, (Dhaka: Raju Art Press, 2010). 


\section{Penutup}

Fitur-fitur Kalam, Falsafah, Fikih, Pendidikan dan Dakwah Sosial di era millinium baru, era negara bangsa modern telah digambarkan dan dipetakan diatas. Bagaimana hubungan antara beberapa dan berbagai item dan komponen berpikir keagamaan "baru" tersebut? Terlebih lagi jika ingin diimplementasikan dalam penyusunan silabi, kurikulum, metode perkuliahan pada Perguruan Tinggi Agama Islam di tanah air? Anyaman dan rajutan dari berbagai disiplin, perspektif, sudut pandang keilmuan tersebut itulah yang pada gilirannya akan dapat berkontribusi dalam pembangunan karakter bangsa dan itu pulalah yang ingin saya gagas sebagai Filsafat Islam Keindonesiaan.

Pola hubungan antara satu item berpikir dan lainnya adalah merupakan satu kesatuan berpikir yang utuh, saling terkait, integrated -interconnected. Antara satu item atau tema dan yang lainnya tidak dapat dipisah-pisah. Item-item pemikiran keagamaan tersebut semula memang berdiri sendiri-sendiri, terpisah-pisah, kemudian mengumpul, terhubung, terintegrasi dan terinterkoneksi. Cara berpikir, cara pandang dan pendekatan item-item tersebut bersifat saling menembus (semipermeable), saling memberi masukan dan menguji (intersubjective testability) danmemerlukan imaginasi kreatif yang kuat (creative imagination) $^{32}$ antara yang satu dan lainnya. Masing-masing membentuk network atau jaringan dan proses berpikir keagamaan Islam yang utuh. Masing-masing berperan dalam dirinya sendiri dan sekaligus berperan dalam membentuk secara utuh keutuhan world view keagamaan Islam era kontemporer. Keutuhan world view keagamaan yang menggunakan pendekatan multidisiplin, interdisiplin dan pluridisiplin akan membentuk cara pandang keagamaan dalam diri seseorang atau kelompok yang bercorak transdisiplin. Diharapkan ke semua item tersebut disadari oleh masingmasing aktor di masyarakat, baik status sosial nya sebagai guru, guru ngaji, pimpinan majelis taklim, pimpinan pesantren, pegiat dakwah, ustadz, kyai, ajengan, tuan guru, dosen, pimpinan masyarakat dan pimpinan negara dan kemudian mampu mendialogkan dan mendiskusikan dalam satu keutuhan berpikir keagamaan dan keislaman yang utuh. Tidak mudah memang mengajarkan agama pada era perubahan sosial yang dahsyat era millinium baru seperti saat sekarang ini. Masih banyak item lain yang belum disentuh, namun dengan landasan dasar berpikir Kalam/Aqidah, Falsafah, Fikih, Pendidikan dan Dakwah Sosial yang baru dan fresh seperti itu, akan mudah mengembangkannya lebih lanjut.

\section{DAFTAR PUSTAKA}

Abdullah, M. Amin, (2006. Islamic Studies di Perguruan Tinggi: Pendekatan Integratif-interkonektif, Yogyakarta: Pustaka Pelajar.

, (2012). "Metode Kontemporer dalam Tafsir al-Qur'an: Kesalingterkaitan Asbab al-Nuqul al-Qadim dan al-Jadid dalam Tafsir al-Qur'an Kontemporer”, Jurnal Studi Ilmu-ilmu Al-Qur'an dan Hadis, Vol. 13, No. 1, Januari, h. 1-21.

_, (2013). “Agama, Ilmu dan Budaya: Paradigma Integrasi-Interkoneksi Keilmuan”, Pidato Inaugurasi sebagai anggota Akademi Ilmu Pengetahuan Indonesia (AIPI), UGM, Yogyakarta, 3 September.

${ }^{32}$ Lebih lanjut lihat pidato inaugurasi saya sebagai anggota Komisi Kebudayaan, Akademi Ilmu Pengetahuan Indonesia (AIPI), di UGM, Yogyakarta, tanggal 3 September 2013, “Agama, Sains dan Budaya: Paradigma Integrasi-Interkoneksi Keilmuan”, http://goo.gl/43m'TBI. 
Ahmad, Mariam Ait, (2013). al-Mar'ah al-muslimah baina tabaddiyat al-tamkin wa mustaqbalah al-tanmiyah, al-Qahirah: Dar al-Salam.

Auda, Jasser, (2008). Maqasid al-Shariah as Philosophy of Islamic Law: A Systems Approach, London: The International Institute of Islamic Thought.

Baderin,Mashood A., (2003). International Human Rights and Islamic Law, Oxford: Oxford University Press.

Bennett, Clinton, (2005). Muslims and Modernity: An Introduction to the issues and debates, London: Continuum.

Dzuhayatin, Ruhaini Siti et.all, (Ed.), (2013). Menuju Hukum Keluarga Progressif, Responsif Gender dan Akomodatif Hak Anak, Yogyakarta: Suka Press, PSW UIN Sunan Kalijaga, the Asia Foundation.

Ess, Josef van, (1992). "The Logical Structure of Islamic Theology”, dalam Issa J. Boullata (Ed.), An Anthology of Islamic Studies, Montreal: McGill Indonesia IAIN Development Project.

al-Ghazali, Muhammad, (1989). al-Sunnah al-Nabawiyyah baina abl al-figh .. wa abl al-hadits, Bairut: Dar al-syuruq.

Goma’a, Shaykh Ali, "A Common Word Between Us and You”: Motives and Applications”, dalam Waleed el-Ansary dan David K. Linnan (Ed.), (2010). Muslim and Christian Understanding: Theory and Application of "A Common Word", New York: Palgrave McMillan.

Guessoum, Nidhal, (2011). Islam's Quantum Question: Reconciling Muslim Tradition and Modern Science, London dan New York: I.B. Tauris and Co Ltd.; terjemahan dalam bahasa Indonesia oleh Maufur, (2014). Islam dan Sains Modern, Bandung: PT Mizan Pusataka.

Haddad, Yvonna Yasbeck, (2002). Muslims in the West: From Sojourners to Citizens,Oxford: Oxford University Press.

Hanafi, Hasan dan M. Abid al-Jabiri, (1990). Hiwar al-Masyriq wa al-Maghrib: Nabw i'adati bina'i al-fikr al-qaumi al-araby, Beirut: al-mu'assah al-arabiyyah li al-dirasah wa al-nasyr.

Hanafi, Hasan, (2004 DAN 2005). Min al-Nash ila al-Waqi': Muhawalah li i'adati binai ilm usul al-fiqh, Buku 1 dan 2, al-Qahira: Markaz al-Kitab li al-nasyr.

Hunt, Robert A. and Yuksel A. Aslandogan (Ed.), (2006). Muslim Citizen of the Globalized World: Contribution of the Gulen Movement, New York: The Light Inc. \& IID Press.

Khan, Md. Maimul Ahsan, (2010). Introducing Fethullah Gulen to Bengal and Beyond, Dhaka: Raju Art Press.

Markham, Ian dan Ibrahim M. Abu Rabi' (Eds.), (2002). 11 Sepetember : Religious Perspectives on the Causes and Consequences, Oxford: Oneworld Publications.

Meijer, Roel, (2009). Global Salafism: Islam's New Religious Movement, London: Hurst \& Company. 
Moosa, Ebrahim, "Introduction", dalam Ebrahim Moosa (Ed.), (2000). Revival and Reform in Islam: A Study of Islamic Fundamentalism Fazlur Rabman,Oxford: Oneworld Publications.

al-Naim, Abdullahi Ahmed, (1990). Toward an Islamic Reformation: Civil Liberties, Human Rights, and International Law, New York: Syracuse University Press.

Ramadan, Tariq, (2004). Western Muslims and the Future of Islam, Oxford: Oxford University Press.

Saeed, Abdullah, (2006). Interpreting the Qur'an: Toward Contemporary Approach, London: Oneworld Publications.

al-Talbi, Muhammad, (1992). 'Iyalu al-Allah: Afkar Jadidah fi 'alaqah al-Muslim bi nafsibi wa bi al-akharin, Tunisia: Dar siras li al-nasyr.; Mariam Ait Ahmad, Jadaliyyatu al-Hiwar: Qira'ah fi al-Khitab alIslamiy al-mu'asir, 2011. 
